\title{
Education: An Essay on the Legacy of European Colonialism
}

\author{
Zhuoxi Ye \\ 6856 N Vista St, USA. \\ lisa.ye.19@alvernoheights.org
}

Abstract: European colonization took place from the early 15th century until the early 19th century. Over 400 years, European countries had dramatically changed and influenced their colonies. European ideas did not only impact the economy and the culture, but also social welfare and people's thoughts. The consequences of European colonialism are identified today as colonial legacies. This article discusses a colonial legacy -education - and the effects that this has had in India and China.

European Colonialism refers to the worldwide expansion and exploration of countries by European powers, beginning in 1500. With the spread of the ideas from the Renaissance and the Age of Enlightenment in the fifteenth and sixteenth centuries and later, technology from the Industrial Revolution in the eighteenth and nineteenth centuries, much of the world has been influenced by European countries, such as Britain, Spain, Germany, and France. These European colonies extended across Asia, Africa, North America, and South America and included an enormous diversity of people and cultures. According to the Oxford Dictionary of Politics ${ }^{1}$, colonialism is the policy and practice of a strong power extending its control territorially over a weaker nation or people. However, beyond its original definition, colonialism is often associated with imperial powers which conquer other countries to exploit natural resources for economic gain. In capitalizing on these financial opportunities, colonialism also challenges the social, economic, and religious structures of the indigenous people, One major way European thinkers asserted dominance and order in colonial societies was through local education. Education was a crucial factor in society because it preserved European social structures and power over the native people while conveying ideas which supported systems of profit for the mother country. Therefore, in order to preserve social order and ensure the elite economic standing of European leaders in colonial societies, European nations began to reorganize and reinforce their colonies' education systems, a significant legacy which still has consequences today.

Influenced by the Age of Enlightenment, a typical western education system mainly focused on understanding knowledge through logical reasoning. It was first brought to the East by the European missionaries who were willing to explore the world while spreading Christianity. Charles Grant, the father of modern education in India, felt that Indians needed to be first educated and finally converted to Christianity. However, in most Eastern countries, such as India, education was still bonded with local religious beliefs. So if the European countries wanted to assimilate or manage the colonies, the first step was to abandon the colonies' old, religious-related education system held for many years by indigenous people.

Prior to the British era of colonization in India, schools were supported by public donation, and only the children from the upper castes were provided with formal education. Upon the limitation of social classes, the local religious institutions had the total control of the schools. So, in some parts of India, if a Hindu family living in a Muslim-dominated area wanted to send their children to school, they first would have to convert their religion to Islam in order to gain access to the school system. When the British began to occupy India with the

1. The Concise Oxford Dictionary of Politics (3 edition) Lain McLean and Alistair McMillan

www.arjonline.org

Page 1 
cooperation of British East India Company, they decided to introduce English as the medium of instruction to replace Persian. At the same time, they established the Anglo Education System, which classified schools in terms of Primary, Upper Primary, Elementary, Secondary, and Senior Secondary as well as introduced a standardized curriculum that boosted literacy. Now, more children, not just those from the privileged classes and local religious backgrounds had access to education. This is evident from "Educational Statistics At a Glance" ${ }^{2}$, who testified that, i. In addition to providing a platform where English, the common language for communication could be taught to thousands of Indian children, the British had other goals in designing the education system in this colonial society. In 1835, Thomas Macaulay articulated the goals of British colonial imperialism most succinctly when he stated, "we must do our best to form a class who may be interpreters between us and the millions whom we govern, a class of persons Indian in blood and colour, but English in taste, in opinions, words and intellect." Thus, English schooling not only provided an efficient means of communication that helped the British manage their empire, but also established the English education system and culture as one that was privileged and valued while the local customs and beliefs were seen as inferior.

The influence of British colonial rule in India was the catalyst to further advance education in the modern age. With a Western curriculum previously introduced by the British, India established a dense education network following its independence from the British Empire. Universities were built and managed according to the western model introduced under the colonial regime and the old system based on religion was entirely abandoned. Additionally, school enrollment experienced a significant change. For example, "as per the Annual Status of Education Report (ASER) 2012, 96.5\% of all rural children between the ages of 6-14 were enrolled in school. This is the fourth annual survey to report enrollment above 96\%. Another report from 2013 stated that there were 22.9 crore students enrolled in different accredited urban and rural schools of India, from Class I to XII, representing an increase of 23 lakh students over 2002 total enrollment, and a 19\% increase in girl's enrollment." Until this day, India still uses English as the medium of instruction. While traveling in India, people can communicate easily with locals in English, which facilitates many of the obstacles in a country where the majority of people are multilingual and speak a a range of dialects.

However, despite its independence and control over institutions, including the education system, colonial mentality continues to occur in India to this day. Colonial mentality is defined as an internalized racial oppression and the ethical or cultural inferiority felt a people as a result of colonization. Because of the constraint and years of subjugation of British, India has experienced many damaging changes and altered sociocultural views that they were not prepared for. The evolving study of British cultures and ideas taught in schools which were elevated and valued in colonial society subconsciously reinforced the indigenous population to favor British values and practice British lifestyle at the expense of their own traditions and beliefs. The effects of colonial mentality did not disappear with Indian independence from Britain in August 1947, but instead remained embedded into the fabric of Indian society and everyday life. Because India had been subjected to colonial rule for several decades, it would take years for the Indian government to recover, settle their own system, and reclaim their cultural identity. Yet due to the limitation of funds, overpopulation, and other national issues, India continues to develop and separate from he effects of its colonial heritage. British colonial rule had created an inferiority complex in the way that Indians viewed their mother languages and culture and this can not be resolved until significant political, education, and language policy is introduced. The education system created by the British purposefully excluded the teaching of native cultures, languages, and traditions in the classroom. Today, many schools continue this tradition, which in dadvertently advances colonialism in modern India.

2. "Educational Statistics At a Glance", Government of India Ministry of Human Resource Development Department of School Education \& Literacy Statistics Division New Delhi, 2018 
In addition to Britain's colonial influence on India, the traditions and standards of this imperial nation have and continue to affect global education trends elsewhere in the world. For example, the GCE Advanced Level, a main school-leaving qualification in England, Wales, Northern Ireland, the Channel Islands and the Isle of Man, is widely adopted all over the world, including in places such as Singapore, Kenya, Mauritius, the United States, and Zimbabwe. Furthermore, the influences of western education are especially emphasized in countries or cities that previously were influenced by European colonization, such as India, Shanghai, Hong Kong, and countries in Africa.

The diversified education in China exemplifies the influence of a colonial legacy on education. Despite having both political and commercial centers, Shanghai, compared to Beijing, adapted western culture more successfully and extensively. To illustrate this, there are almost 40 international schools in Shanghai and these schools are presided over by educators from many European countries and the United States. Additionally, western countries' colleges are more likely to settle their international campus in Shanghai, including New York University, Duke, and UC-Berkeley. These colleges and international schools reside in Shanghai and not Beijing because of the history of colonization of in this city under the Treaty of Nanking. The previous historical influence of European colonization has created a global understanding of Shanghai society's ability to adapt to and accept western education systems. Even in China, people agree that, besides Hong Kong, Shanghai is the most globalized and "trendy" city, a belief that reflects the continuation of a colonial mentality in China. The majority of families with a higher standard of living expect to send their kids to Shanghai for middle or high schools in order to "integrate with the world", a common expectation Chinese parents have for their kids. After graduating from international high school, kids very frequently choose to go abroad for universities in Britain, the United States, and Germany etc. Thus, the western cultural imprint left by European colonization, and the way western education systems are viewed by the Chinese in particular, allows cities like Shanghai to have broader global connections but lowers the prestige of Chinese culture and schools.

While the legacy of colonialism can help advance the level of education in some countries, people must protect their cultural identity and heritage by recognizing the remnants of colonialism and establishing boundaries between their nation and their former colonizers. The case studies in Indian and Shanghai illustrate a situation where when education is "over-westernized", people begin to neglect their own culture. In response, some governments are instituting changes to prevent further damage from colonialism. For instance, the Chinese government has taken action to bring back and emphasize the traditions. Millions of dollars have been allocated to producing TV shows on traditional cultures and poems; advertisements are hung around cities to communicate messages to communities, and museums introduce culture and historical creative goods. This effort seems to have a positive effect because in 2017 alone, the department of creative goods of the Forbidden City profited over two hundred million yuans. In spite of this success, a greater challenge exists for countries which have been colonized for a longer period of time. As a result of their long colonial history, these nations are less likely to have the economic or political strength to establish efficient solutions, and thus must continue under social and cultural uncertainty. These nations countries eventually must undertake the responsibility of dealing with the effects of colonial legacies, especially those in education systems in order to advance the future of the whole country.

\section{REFERENCES}

1. "US Schools Setting Up Campuses in China" Lia Zhu, 2018, “ China Daily" http://usa.chinadaily.com.cn/ a/201801/25/WS5a699e74a3106e7dcc136a42.html

2. “Colonialism And Education" Nwanosike and Onyije, 2011

3. "Identity, colonial mentality, and decolonizing the mind: exploring narratives and examining mental health implications for Filipino Americans" Ashley M. Decena, 2014 
Education: An Essay on the Legacy of European Colonialism

4. "Impact of Colonialism on Education" Edward Shizha, Michael T. Kariwo, 2011

5. "The Colonial Legacy in Indian Education" Harvard Graduate School of Education Magazine

6. "The Times of India" Himanshi Dhawan, 2013, " Enrolment in schools rises 14\% to 23 crore"

7. "Impact of Colonialism on Education", Impact of Colonialism on Education, University of Oran Es- Senia, Faculty of Letters, Languages and Arts, Department of Anglo- Saxon Language Section of English, 2010 2011

8. "Educational Statistics At a Glance", Government of India Ministry of Human Resource Development Department of School Education \& Literacy Statistics Division New Delhi, 2018

Citation: Zhuoxi Ye. "Education: An Essay on the Legacy of European Colonialism". American Research Journal of Humanities and Social Sciences, vol 4, no. 1, 2018, pp. 1-4.

Copyright (C) 2018 Zhuoxi Ye. This is an open access article distributed under the Creative Commons Attribution License, which permits unrestricted use, distribution, and reproduction in any medium, provided the original work is properly cited. 